\title{
The Use of Quizlet Flashcard Software and Its Effects on Vocabulary Learning*
}

Yağmur Ersoy Özer** - Zeynep Koçoğlu ${ }^{* * *}$

Abstract

The main goal of this paper is to investigate the effect of two vocabulary learning approaches: 1) Computer-assisted Language Learning (CALL) with a computer-based flashcards program, Quizlet, 2) Keeping vocabulary notebooks on high school EFL learners' vocabulary learning. The vocabulary targeted for the study is determined from three sequential units of the textbook. The units are selected randomly considering the starting date of the study. Eighty-nine students in four beginner EFL classes were assigned as control or treatment groups. The flashcard software program (Quizlet) and paper-based vocabulary notebook was implemented in two different classes over a week period. The remaining two classes were control groups following the same curriculum with the same materials without using Quizlet or keeping vocabulary notebooks. Vocabulary learning and recall was measured by pre, post and delayed post-tests of unannounced vocabulary tests including knowledge of orthography, grammar and use adapted from Laufer and Goldstein (2004) and, meaning and form, adapted from Webb

\section{Quizlet Flashcard Programının Kullanımı ve} Kelime Öğrenimi Üzerindeki Etkisi

$\mathrm{Bu}$ çalışmanin temel hedefi kelime öğrenme yöntemlerinden iki tanesinin etkisini araştırmaktır: 1)Quizlet, kelime kartları dijital programin kullanarak, bilgisayar destekli yabancı dil (İnilizce) öğreniminin kelime ögrrenimine etkisi, 2) İngilizce'yi yabancı dil olarak öğrenen lise öğrencilerinin kelime defteri tutarak öğrenmelerinin kelime öğrenimine etkisi. Araştırmadaki hedef kelimeler, ders kitabında art arda gelen üç üniteye göre karar verildi. Rastgele seçilen üniteler çalışmanın başlangıç tarihi düşünülerek seçildi. Başlangıç seviyesinde, Ingilizce'yi yabancı dil olarak ögrenen başlangıç seviyesinde 4 sinıfa control veya deneysel grup olmak üzere görev verildi. Bilgisayar destekli kelime kartları programı vekağıt tabanlı kelime defteri, iki farkl sinıfa 3 haftalik bir süre içinde uygulandi. Kalan iki sınıf, aynı müfredat ve materyalleri, Quizlet veya kelime defteri kullanmaksizin takip eden control gruplariydi. Kelime ögrenimi ve hatırlanması, Laufer ve Goldstein'den (2004) uyarlanan yazım, gramer ve kullanim; Webb'ten (2009) uyarlanan anlam

\footnotetext{
* Bu makale yazarın yayınlacak olan tez çalışmasından uyarlanmıştır.

** Bahçeşehir Çamlıca Koleji.

*** Yrd. Doç. Dr., Yeditepe Üniversitesi.
} 
(2009). Pre, post and delayed post-test scores were analyzed to evaluate the effectiveness of vocabulary learning and retention. The results show that there was no significant difference about vocabulary learning and recall among the groups. However, the improvements were observed between pre-test/ post-test and pre-test/ delayed post-test among control, Quizlet and vocabulary notebook groups.

Keywords: Vocabulary Learning; Intentional Vocabulary Learning, Computer-Assisted Language Learning, Multimedia Learning,Dual Coding Theory, Using Flashcards and KeepingVocabulary Notebooks in Vocabulary Learning. ve yapı bilgisi ögrencilere önceden duyurulmadan yapılan pre, post ve delayed post test kelime testleri ile ölçüldü. Test sonuçları kelime öğreniminin ve hatırlanmasının etkisini değerlendirmek için incelendi. Sonuçlar gösterdi ki, gruplar arasında kelime öğrenimi ve hatırlanması ile ilgili belirgin bir farklilik gözlenmedi; fakat control, Quizlet ve kelime defteri tutan katılimcilar arasinda pre-test/ post- test ve pre-test/ delayed post-test arasinda gelişmeler gözlemlendi.

Anahtar kelimeler: Kelime Öğrenimi, İsteyerek (Kasıtlı) Kelime Öğrenme, Bilgisayar Destekli Dil Öğrenimi, Çoklu Ortamda Öğrenme, İkili Kod Teorisi, Kelime Öğreniminde Sözcük Kartlarının Kullanılması, Kelime Defterler. 


\section{Introduction}

Vocabulary knowledge is a crucial component of learning English as a foreign language (EFL). Wilkins (1972) says "without grammar very little can be conveyed, without vocabulary nothing can be conveyed" (p. 111). Supporting Wilkin's claim and regarding the studies on lexical competence and its effect on language teaching, Fowle (2002) asserts language teachers begin to question an efficient way of vocabulary teaching to meet the needs of students. In order to investigate an effective way of learning, the current study examined two vocabulary learning approaches, CALL (Computer Assisted Language Learning Program) and vocabulary notebooks.

According to the Ministry of Education, medical high schools' curriculum has six lesson hours in a week at $9^{\text {th }}$ grade and three lesson hours in a week at $10^{\text {th }}$ grade. The learners also do not have English lessons at $11^{\text {th }}$ and $12^{\text {th }}$ grades. The purpose of EFL high school learners ( $9^{\text {th }}$ and $10^{\text {th }}$ graders) was to gain and retain new, adequate number of vocabulary within two years. Considering the needs of student endeavoring to learn new words, an effective and a rapid way of vocabulary learning wasinvestigated. In this sense, Schmitt (2008) and Laufer (2005) suggest intentional vocabulary learning with explicit focus is much faster than incidental vocabulary learning. Therefore, online flashcards programs and vocabulary notebooks providing intentional learning are used. The criteria in determining the flashcard software program from among the popular flashcard programs was its popularity among learners (the number of users) and its practicality (free and available). Quizlet, one of those flashcard programs with its large number of users and free enrollment was preferred to find out the effect on learners' vocabulary development.

\section{Literature Review}

\subsection{What Does It Mean To Know A Word?}

The definition of "knowing a word" requires a deep knowledge of receptive (the perception of word forms and getting their meaning) and productive vocabulary use (the expression of meaning in an appropriate spoken or written context) (Nation, 2000).Form, meaning and use are three components of word knowledge respectively. Knowing word form is the recognition of the word parts, spoken andwritten forms of the vocabulary including how a word is pronounced (spoken), how a word is spelled (written) and what word parts are necessary to give the meaning (word parts). On the other hand, word meaning refers to the knowledge of meaning (what the target word means), concepts and referents (what underlying meaning the word has in different contexts) as well as associations (what other words we can use instead of the target vocabulary). Lastly, knowing word use refers to 
grammatical functions, collocations and constraints on use. Word use identifies, what type of words come together with that word (collocations) and where, when and how often we can use this word (constraints on use) (Nation, 2000).

\subsection{Incidental and Intentional Vocabulary Learning}

Current approaches to vocabulary learning comprise two paradigms of implicit and explicit learning (Ma and Kelly, 2006). Implicit vocabulary learning refers to acquiring vocabulary subconsciously with repeated exposure in communicative activities, whereas explicit vocabulary learning needs conscious effort to build up new target words. Schmitt (2008) supports that intentional vocabulary learning with an explicit focus facilitates learning large amount of words in a short period of time as well as a better chance of retention. In a similar vein, File and Adams (2010) investigate the effects of isolated or integrated form-focused instruction on vocabulary development and retention. In the study, the first treatment group got the new words isolated before reading; the second group was exposed to the new words integrated during reading. The control group tried to learn the target words incidentally. The results show that the groups learning vocabulary isolated or integrated through intentional learning performed better outcomes than the group learning incidentally. Similarly,Laufer (2003) opposes incidental vocabulary learning and claims that L2 learners need to read around 200.000 words in a context in order to learn 108 target words subconsciously. Laufer (2005) also notes that learners gain 70 percent of the new words that take place on posttests immediately after explicit vocabulary exercises.

The difference between intentional \& incidental learning seems in the presentation of vocabulary tests as well. Intentional vocabulary learning allows learners to be informed for an upcoming test, whereas no information is given for an upcoming test beforehand in incidental vocabulary learning (Laufer\&Hulstijn, 2001). In this study, an intentional vocabulary learning strategy is used as the instructional strategy because the participants in the research have difficulty in learning and retaining the new vocabulary over a short and limited period of time. The learners are informed about the immediate and delayed posttest assessing orthography, meaning and form and grammatical knowledge of selected target vocabulary.

\subsection{Learning From Flashcards}

Nation (2000) defines word cards as writing a foreign word and its meaning on front and back sides of a small card. The meaning can be in the form of a first language translation, definition or a visual. The purpose is to get the meaning of a new vocabulary and check it 
rapidly through turning the card over. Nation (2000) mentions word cards enable learners to get orthography of the word and to make connections between form and meaning. He exemplifies the meaningful way of learning through flashcards by comparing "vocabulary notebooks and vocabulary lists" with the use of word cards. He states the learners get the word and its meaning simultaneously in vocabulary lists and notebooks while the learners using word cards turn the meaning of the target word when they need it. Therefore, flashcards facilitate to get the meaning of the word from the memory. Furthermore, recent studies show that vocabulary learning through flashcards is a priceless vocabulary learning activity supporting pair-associated learning which provides learners to memorize a lot of words in a limited time (Webb, 2009). Similarly, Nakata (2011) emphasizes the advantages of computer-based flashcards because of its multimedia capabilities providing enriched presentation of materials and exercises types.

\subsection{CALL Instruction of English Vocabulary Learning}

In 1980's, computer assisted language learning (CALL) started to become popular for language and vocabulary learning. However, the technology was not satisfying enough to enrich the types of vocabulary activities. Text construction, gap-filling, speed reading, simulation and vocabulary games were main exercises to practice new words (Ma \& Kelly, 2006). Vocabulary learning also was not as popular as nowadays in terms of providing different types of vocabulary learning theories.

CALL is currently superior to traditional methods (pencil and paper based activities) with opportunities to practice the language within different types of exercises. For example, Nakata (2011) emphasized the superiority of CALL studying "iKnow!" offering various exercises such as multiple choice questions generated automatically and embedded exercises promoting receptive and productive vocabulary knowledge. Similarly, Kilickaya and Krajk (2010) investigated 38 students from an English language university with an online vocabulary program called "WordChamp" in Turkey. The results demonstrate that online vocabulary learners outperformed the participants being exposed to the traditional instructional methods. In order to investigate the vocabulary retention, the delayed posttest results were overviewed. Two months later after the post-test, while the experimental group had $4 \%$ loss, the control group had $6 \%$ loss of the target vocabulary studied. Moreover, a research study by Nakata (2011) analyzed short and long term effectiveness of two vocabulary learning approaches, CALL with spaced repetition and vocabulary notebooks. The results showed that both treatments were equally well in short term, but the analysis of longer term gains showed that the CALL group (decreased by 5\%) was slightly better than vocabulary notebook group (decreased by 14\%) in statistically proven outcomes of forgetting words. 


\subsection{Multimedia Learning}

Hasebrook (1997) defines multimedia as the interaction of different media types in a computer application. Ashworth (1996) explains interactivity as "the degree to which a user of a program is involved in or has control over that program" (p. 82). Interactive media is the integration of digital sound, image, text and video by using computer with users taking control of their learning process (Watts, 1997).

"Multimedia learning refers to learning from words and pictures. Multimedia instruction refers to the presentation of material using both words and pictures, with the intention of promoting learning" (Mayer, 2001, p. 3). The multimedia is presented by means of the delivery media (e.g., amplified speaker and computer screen), presentation mode (e.g., words and pictures) or sensory modalities (e.g., auditory and visual). The multimedia environments base on drill and practice systems and multimedia learning is respected as information acquisition or knowledge construction (Mayer, 2001).

Paivio (1971) says that human cognition can deal with language, nonverbal objects and events at the same time. Nonverbal/imagery system consists of sensory and visual modalities while language system refers to verbal system. According to dual coding theory (DCT), nonverbal and visual systems are two separate subsystems monitored cognitively. They differ from each other structurally and functionally. Although nonverbal and linguistic systems can be active alone, they are also interconnected in the sense that either system can activate one another (Paivio,1986). Researchers combine these two separate, but interconnected subsystems (nonverbal and linguistic systems) of cognition in vocabulary teaching. Pavio (1971) states that representation of a word with both verbal and imagery codes such as pictures and mental images are better than using verbal codes alone. $\mathrm{He}$ also adds that representing an item with two memory codes provides a better chance of remembering rather than a single code.

\subsection{Keeping Vocabulary Notebooks}

Vocabulary notebooks are defined as "any form of notebook used for recording new and useful vocabulary and some additional information about the word" (McCrostie, 2007, p. 247). Fowle (2002) says the learners get the chance of making definitions, explanations and practicing about translation, parts of speech, pronunciation, collocations, antonyms, and synonyms through analyzing word families, designing mind maps and grammatical categorization in the notebook.In this study, "vocabulary notebook" refers to the written material that learners note down the new words they have encountered, with their meanings, parts of speech, synonyms, antonyms and sentence construction. 
Schmitt and Schmitt (1995) argue that vocabulary notebooks enable language learners a deep understanding of the word's meaning. The students keeping the notebooks pay attention on new lexical items and consolidate the target words. Hence, they enhance vocabulary study and enrich the number of words they acquire (Fowle, 2002).

\section{Methodology}

The current study aimed to examine the effects of vocabulary learning tools (Quizlet and vocabulary notebook) on vocabulary learning and recall of beginner level foreign language learners enrolled in a medical vocational high school, in Istanbul, Turkey. Participants were measured by vocabulary tests of orthography and grammar (adapted from Laufer\& Goldstein, 2004), and vocabulary tests of meaning and form (adapted from Webb, 2009).

\subsection{Research Methods}

This study is a quantitative research analyzing the relations between two experimental groups (Quizlet-flashcard software program and vocabulary notebook) and a control group (with no treatment).

\subsection{Setting and Participants}

The research took place during the second semester of 2013/2014 school years at a private vocational high school in Turkey. The target population was junior students of a private medical vocational high school. The participants studied English for six hours per week as a compulsory course determined by the Ministry of Education. There were eight units in the course book in total. Three out of eight units at the first term and five out of eight units at the second term were aimed to be completed.

Four classes (two experimental and two control groups) with 89 participants took part in the study. The research was conducted with $9^{\text {th }}$ graders and their age ranged between 15 and 16 years old. Cambridge ESOL Key English Test (KET) administered at the beginning of the year and students were placed into Al level within the requirements of Common European Framework. One class served as the treatment group "A" using Quizlet, vocabulary software program with flashcards, one class served as the treatment group "B" keeping the vocabulary notebooks. The remaining two classes constituted the control groups without any treatment.

There were 55 female and 34 male students in the study. The groups were chosen randomly. In the treatment group A (Quizlet), there were 4 males and 16 females $(N=20)$, in the 
treatment group B (Vocabulary Notebook), there were 13 males and 13 females $(N=26)$, in the control groups, there were 17 males and 26 females $(N=43)$. The participants were homogenous in terms of their ages, proficiency levels and native languages. A teacher, as a researcher, mentored the study.

\subsection{Instructional Materials}

\subsubsection{Description of the Computer-Based Flashcard Program (Quizlet)}

A flashcard software program, Quizlet, was used in the present study to help beginner level EFL learners improve their vocabulary knowledge. This software was an effective learning tool that helps students memorize and recall key concepts of different subjects such as geography, math, vocabulary or language learning. Quizlet is an online vocabulary learning tool with 40 million users every month (Quizlet, 2016).

Users can study with Quizlet on their own computer, on their cell phones with mobile apps (iPhone or Android) or other devices such as iPad and iPod Touch. Access to the program is free after creating an account. There are numerous flashcard sets on different topics and users can also create their own sets. The program is similar to paper flashcard system with the question on the front and the answer on the back. However, unlike traditional, paper-based flashcards, learners can insert visuals by uploading the images corresponding to the target word. When the learners click on 'Audio on' button, they canalso hear the pronunciation of the word. Hence, Quizlet, with its feature, supports Mayer's multimedialearning framework such that "people learn better from words and pictures than from words alone" (Mayer, 2005, p. 31).

The criterion in choosing the flashcard software program from among the popular flashcard programs (e.g., Vtrain, Anki, SuperMemo) was its popularity among people first of all. The purpose was to measure a flashcard software program preferred by large numbers of people, so Quizlet, with one million users, was selected for the study. Secondly, the program has been simple and user-friendly, thus learners easily get accustomed to its use. Next, it is possible to integrate multimedia capabilities (e.g., pronunciation of words, inserting visuals) which provide learners with much more interesting and motivating learning environment. Additionally, the access has been free; the users can create their own account without any payment.

The main set offers different ways to study the terms and definitions. There are 6 study and game modes including (a) flashcards, (b) learn, (c) speller, (d) test, (e) scatter and (f) space race 


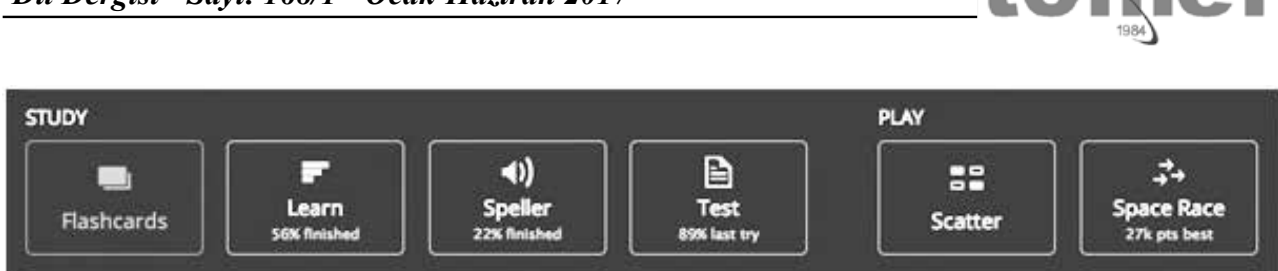

(a) Flashcards

Flashcards enables learners to choose motions ("flip" or "flow") they prefer to hear pronunciation of the vocabulary (audio on/off) and to see term first, definition first or both sides at once.

(b) Learn Mode

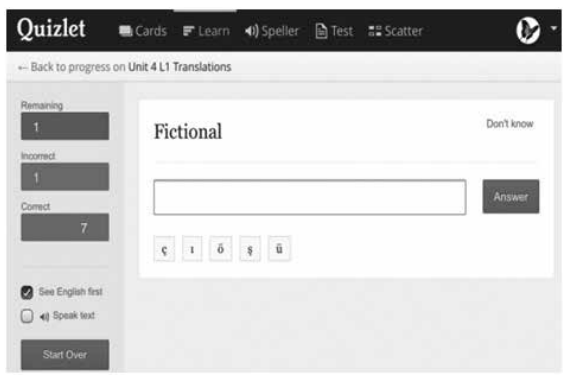

Learn Mode measures user's knowledge of the target vocabularies. The word sets serve as prompts. The test requires learners to type the answer (a term or a definition). Quizlet marks correct or incorrect answers and gives users opportunity to see the questions they've missed. If the learner does not know the answer, she/ he can leave the question. At the end, the total number of words missed or correctly answered is reported.

\section{(c) Speller}

Speller specifically helps learners practice pronunciation and spelling of the target vocabulary. The users are expected to type what they hear. Quizlet corrects spelling mistakes and asks to retype. The study finishes when each term is spelled fully correct. At the end of the test, learners see the words missed or correctly spelled with percentages.

(d) Test

Test generates a random test including written and matching, true/false and multiple choice questions for flashcard sets created.

\section{(e) Scatter}

Scatter is a game like matching activity of terms and definitions recorded in learners 'study sets. The more the learner finishes in a short period of time, the more possible to get high points. 


\section{(f) Space Race}

Space Race is a game of typing terms (or definitions) while the definitions (or terms) are scrolling across the screen. All of the words (terms and definitions) are from among the sets that the learners formed beforehand. When the users miss the question, Quizlet guides the learner to retype the answer.

\subsection{Data Collection Instruments}

\subsubsection{Vocabulary Familiarity Test}

In order to eliminate known words, a vocabulary familiarity test including all words of the target units was administered. Students were asked to write Turkish meanings of given English words. According to the test results, learners were unfamiliar with 42 out of 123 words. Even a word known by a learner was eliminated and the target words were determined.

\subsubsection{Vocabulary Tests}

Vocabulary tests were created using the target words that appeared in the units to be covered over the 3 -weeks period. The vocabulary tests were used as pretest, posttest and delayed- posttest for each group.

The data was collected through 8 vocabulary tests measuring knowledge of orthography, grammatical functions (adapted from Webb, 2009) and meaning \& form (adapted from Laufer\& Goldstein, 2004). The aspects of vocabulary knowledge emphasized (orthography, meaning and form, and grammar) were measured receptively and productively. In order to reduce the influence of earlier tests on following parts, participants got vocabulary tests one after another. In the pilot study, each test took participants ten minutes to complete, so 10 minutes were allotted to each part of the vocabulary tests. The vocabulary tests administered were described respectively as follows:

Test 1 Receptive knowledge of orthography

Receptive knowledge of orthography (adapted from Webb, 2009) was designed in the form of a multiple choice test format which required learners to circle the correctly spelled target words. In order to measure students' recognition of accurate spelling, the distracters and the target vocabulary were quite similar to each other phonetically and orthographically.

\section{Test 2 Productive knowledge of orthography}

Productive knowledge of orthography (adapted from Webb, 2009) required learners to write target words in 10 seconds after hearing each vocabulary pronounced twice. The test aimed to measure whether the students could produce the correct spelling or not. Spelling mistakes were marked incorrect. 
- Says: $168 / 1 \cdot 0$ cak-Hlaziran 2017

Test 3 Meaning and form

Knowledge of meaning and form tests were carefully sequenced according to the hierarchy of difficulty supported byLaufer\& Goldstein (2004). In the light of their study, active recall proved to be more difficult than passive recall and active recognition needs much more advanced level of knowledge than passive recognition.

Passive recognition test required students to choose L1 (Turkish) translation ofL2 (English) target word from among four options of L1 words. The aim was to measure students' recognition of L2 words (Laufer\& Goldstein, 2004). On the other hand, active recognition test required students to choose $\mathrm{L} 2$ translation of $\mathrm{L} 1$ target word from among four options of $\mathrm{L} 2$ words. The purpose was to measure students' recognition of $\mathrm{L} 1$ words. In addition to recognition tests, recalling tests were applied as well. Passive recall test required learners to write the $\mathrm{L} 1$ translations of $\mathrm{L} 2$ words. The purpose was to demonstrate understanding of L2 word's meaning. Similarly, active recall tests wants learners to write L2 translations of L1 words. The first letter of the translation was provided to keep students from writing nontarget words. Lastly, grammatical functions of the target words were measured. Receptive knowledge of grammatical functions (adapted from Webb, 2009) was designed in the form of a multiple choice test format. The test required learners to circle the grammatically correct sentence. The aim was to measure participants' recognition of grammatically accurate form among the L2 sentences.Productive knowledge of grammatical functions (adapted from Webb, 2009) was designed as a sentence construction test. The purpose was to measure whether the learners made grammatically correct sentences or not. The participants were asked to write a sentence with all 42 target words. The criterion was to use target words with grammatical accuracy.

\subsection{Procedures}

A vocabulary familiarity test was used in both treatment and control groups to eliminate known words. Out of three target units 9, 14 and 19 unknown words were determined respectively. The units were chosen randomly considering the starting date of the study. Each unit was aimed to be completed in a week; hence three target units were arranged to be completed within three weeks. Except for assignments, the same lesson plans were administered for both control and treatment groups. The treatment groups (treatment group A, Quizlet, and treatment group B, vocabulary notebook) were assigned with 5 extra vocabulary tasks done with Quizlet and vocabulary notebooks. The assignments were adapted from Schmitt and Schmitt (1995) as follows: (1) translation; translating the target word into Turkish (L1), (2) synonyms; finding out the synonym of the target words, (3) antonyms; finding out the opposite of the target words, (4) parts of speech; deciding on whether the target word is a noun, a verb, an adjective or an adverb and (5) sentence 
construction; writing a sentence with the target words At the end of three weeks, after the treatments had been successfully completed, the posttest was administered to measure vocabulary learning. The delayed-posttest was performed two weeks later with the aim of testing vocabulary recall.

\section{Results}

The purpose of this study was to examine the effects of computer-based flashcard software (Quizlet) and paper-based vocabulary notebooks on vocabulary learning and recall with lower proficiency level learners of EFL. The following hypotheses were tested:

H1: Students will perform differently on the pre-test depending upon whether they are exposed to any tool.

$\mathrm{H} 2$ : Students will perform differently on the immediate post-test depending upon whether they are exposed to any tool when measured immediately after the intervention.

H3: Students will perform differently on the delayed post-test depending upon whether they are exposed to any tool when measured two weeks after the intervention.

$\mathrm{H} 4$ : At least one group will show a significant difference in the mean number of vocabulary terms correctly recalled.

Descriptive statistics:

Means and standard deviations for each set of scores received from the treatment groups on all assessments were calculated. For the purposes of this study, a significance level of a $=.05$ was used to make all determinations of statistical significance. Table 1 demonstrates mean scores of groups (no-tool, Quizlet and notebook) and time (pre-test, immediate post-test and delayed post-test).

Table 1: Means and Standard Deviations by tool type group and vocabulary assessment

\begin{tabular}{|l|l|l|l|l|}
\hline & \multicolumn{1}{|c|}{ Groups } & \multicolumn{1}{c|}{ N } & \multicolumn{1}{c|}{ Mean } & \multicolumn{1}{c|}{ Std. Deviation } \\
\hline \multirow{4}{*}{ Pre-total } & No-tool & 43 & 89,40 & 25,638 \\
\cline { 2 - 6 } & Quizlet & 20 & 99,00 & 30,166 \\
\cline { 2 - 6 } & Notebook & 26 & 99,42 & 26,247 \\
\cline { 2 - 6 } & Total & 89 & 94,48 & 27,026 \\
\hline \multirow{4}{*}{$\begin{array}{l}\text { Immediate } \\
\text { post-total }\end{array}$} & No-tool & 43 & 144,70 & 50,317 \\
\cline { 2 - 6 } & Quizlet & 20 & 207,50 & 59,943 \\
\cline { 2 - 6 } & Notebook & 26 & 188,23 & 56,057 \\
\cline { 2 - 6 } & Total & 89 & 171,53 & 60,043 \\
\hline
\end{tabular}


Dil Dergisi o Sayn: $168 / 1$ ocak-Haziran 2017

\begin{tabular}{|l|l|l|l|l|}
\hline \multirow{5}{*}{ Delayed post-total } & No-tool & 43 & 178,84 & 54,345 \\
\cline { 2 - 5 } & Quizlet & 20 & 246,55 & 56,252 \\
\cline { 2 - 5 } & Notebook & 26 & 221,27 & 57,826 \\
\cline { 2 - 5 } & Total & 89 & 206,45 & 62,013 \\
\hline
\end{tabular}

Examination of the data in Table 1 shows that the pre-test mean scores of each group were almost equal, so the result supported that at the beginning of the study, vocabulary knowledge of participants was nearly similar to each other.

H1: Students will perform differently on the pre-test depending upon whether they are exposed to any tool.

\section{Inferential Statistics:}

To evaluate the first three hypotheses pertaining to the effects of tool type on the vocabulary learning, three separate analyses of variance (ANOVAs) were conducted on the pre-test, immediate post-test, and delayed post-test data provided by the three groups: no-tool, Quizlet and notebook.

To address the first hypothesis (H1) that students will perform differently on the pretest depending upon their type of tool used, a one-way ANOVA was conducted. Results showed that there were not significant differences among the three tool type groups, $F(2$, $88)=1,418, p=.231$, on the pre- test (Table 2 ).

Table 2: One-way ANOVA results for pre-test by tool type

\begin{tabular}{|l|l|l|l|l|c|}
\hline & \multicolumn{1}{|c|}{ Sum of Squares } & \multicolumn{1}{|c|}{ Df } & \multicolumn{1}{c|}{ MS } & \multicolumn{1}{c|}{ F } & Sig. \\
\hline Between Groups & 2155,599 & 2 & 1077,800 & 1,492 & .231 \\
\hline Within Groups & 62118,625 & 86 & 722,310 & & \\
\hline Total & 64274,225 & 88 & & & \\
\hline
\end{tabular}

H2: Students will perform differently on the immediate post-test depending upon whether they are exposed to any tool when measured immediately after the intervention.

To examine the second hypothesis $(\mathrm{H} 2)$ regarding the effects of tool type on the immediate vocabulary test, another one-way analysis of variance (ANOVA) was used. Results indicated that there were no significant differences among the three tool type groups, $F(2$, $88)=10,885, p=.000$, on the immediate vocabulary test (Table 3 ). 
Table 3: One-way ANOVA results for immediate post-test by tool type

\begin{tabular}{|l|l|l|l|l|l|}
\hline & \multicolumn{1}{|c|}{ Sum of Squares } & \multicolumn{1}{|c|}{ Df } & \multicolumn{1}{c|}{ MS } & F & Sig. \\
\hline Between Groups & 64087,495 & 2 & 32043,747 & 10,885 & .000 \\
\hline Within Groups & 253164,685 & 86 & 2943,775 & & \\
\hline Total & 317252,180 & 88 & & & \\
\hline
\end{tabular}

H3: Students will perform differently on the delayed post-test depending upon whether they are exposed to any tool when measured two weeks after the intervention.

To examine the third hypothesis $(\mathrm{H} 3)$ pertaining to the effects of tool type on the delayed vocabulary test, a third one-way analysis of variance (ANOVA) was conducted. Results showed that there were no significant differences among the three media type groups, $F(2$, $88)=.11,347, p=.000$, on the delayed vocabulary test (see Table 4 ).

Table 4: One-way ANOVA results for delayed post-test by tool type

\begin{tabular}{|l|l|l|l|l|c|}
\hline & \multicolumn{1}{|c|}{ Sum of Squares } & \multicolumn{1}{|c|}{ Df } & \multicolumn{1}{c|}{ MS } & F & Sig. \\
\hline Between Groups & 70656,097 & 2 & 35328,048 & 11,347 & .000 \\
\hline Within Groups & 267757,926 & 86 & 3113,464 & & \\
\hline Total & 338414,022 & 88 & & & \\
\hline
\end{tabular}

The ANOVA results for $\mathrm{H} 1, \mathrm{H} 2$, and $\mathrm{H} 3$ are presented in Table 5.

Table 5: One-way ANOVA results for all tests by tool type

\begin{tabular}{|l|c|c|c|}
\hline & Df & F & Sig. \\
\hline Pre-test & 2 & 1,492 & .231 \\
\hline Immediate post-test & 2 & 10,885 & .000 \\
\hline Delayed post-test & 2 & 11,347 & .000 \\
\hline
\end{tabular}

Considering One-way ANOVA results, each group obtained similar scores on each individual administration of the test. Table 5 demonstrates that there were significant differences in student scores on at least one pair of assessments presented to the no-tool group. Therefore, a post-hoc analysis was necessary to determine which test means differed significantly from the others. The first, second and third paired samples t-tests conducted on the data from no-tool group showed significant differences between each administration of the test (between the pre-test and post-test scores, between the pre-test and delayed post-test scores, between immediate post-test and delayed post-test). 
Table 6 shows there were significant differences in student scores on at least one pair of assessments taken by the Quizlet group.

Table 6: Tests of Within-Subjects Effects for the Quizlet group

\begin{tabular}{|l|l|l|l|l|l|}
\hline & \multicolumn{1}{|c|}{ Type III Sum } & & & & \\
\hline Source & \multicolumn{1}{|c|}{ of Squares } & \multicolumn{1}{c|}{ Df } & \multicolumn{1}{c|}{ Mean Square } & \multicolumn{1}{c|}{ F } & Sig. \\
\hline Group & 233787.700 & 1.828 & 127897.622 & 130.581 & .000 \\
\hline Error & 34016.967 & 34.731 & 979.451 & & \\
\hline
\end{tabular}

A post-hoc analysis was again necessary. In all comparisons, the differences between scores met the requirement of significance, $(\mathrm{a}=.05)$. The results indicated that students in the Quizlet group experienced significant increases in vocabulary scores between the different administrations of the tests.

The results presented in Table 7 indicated that there were significant differences in student scores on at least one pair of tests taken by the notebook group.

Table 7: Tests of Within-Subjects Effects for the notebook group

Type III Sum

\begin{tabular}{|c|c|c|c|c|c|}
\hline Source & of Squares & Df & Mean Square & $\mathrm{F}$ & Sig. \\
\hline Group & 206481.872 & 2 & 103240.936 & 156.539 & .000 \\
\hline Error & 32976.128 & 50 & 659.523 & & \\
\hline
\end{tabular}

In order to determine which tests were significantly different from the others, three paired samples t-tests were conducted as post-hoc analyses.

All significance values are greater than .05 , so the results indicated that students in the notebook group experienced significant increases in vocabulary scores between each administration of tests.

$\mathrm{H} 4$ : At least one group will show a significant difference in the mean number of vocabulary terms correctly recalled.

Hypothesis four is concerned the change in participants' vocabulary scores over time. A repeated measures ANOVA was used to determine whether any change in vocabulary 
learning (i.e., the dependent variable) is the result of the interaction between "groups" ("no tool", "Quizlet" or "notebook") and "time" (pre-test, immediate post-test, delayed posttest). The results are shown in Table 8.

Table 8: Repeated Measures Analysis of Variance Between Subjects and Within Subjects

\begin{tabular}{llll}
\hline Source & $d f$ & $F$ & $P$ \\
\hline Group & 2 & $\begin{array}{l}\text { Between subjects } \\
9,63\end{array}$ & .000 \\
\hline & & Within subjects & \\
\hline Tests & 2 & 467,583 & .000 \\
Tests x Groups & 4 & 12,024 & .000 \\
Error(tests) & 172 & & \\
\hline
\end{tabular}

The repeated-measures ANOVA shown in Table 8 indicated that significant differences were found between group mean scores across all of the tests used in the study. This may indicate that tools used in this study generally had a significant impact on vocabulary learning.

\section{Discussion}

The first research question was "Which vocabulary learning tool (no tool, Quizlet vocabulary software and vocabulary notebook) lead to more vocabulary learning and recall?" There were four hypotheses related with the first research question. To address the first three hypotheses, there were no significant differences among the tool type groups. In other words, each group obtained similar scores on each individual administration of the test.

The results of paired samples t- test for the Quizlet group demonstrated that there were significant differences between pre-test/post-test and pre-test/delayed post-test. The findings are attributable to the advantages of using flashcards and computer assisted language learning (CALL) with multimedia capabilities. Quizlet flashcard software is a sample of computer-assisted language learning (CALL) defined by Levy (1997) as "the search for and study of applications of the computer in language teaching and learning" (p. 1). 
Multimedia learning refers to learning from words and pictures. Multimedia instruction refers to "the presentation of material using both words and pictures, with the intention of promoting learning” (Mayer, 2009, p. 5).The definition of multimedia learning has produced convincing evidence that Quizlet flashcard program provides users multimedia learning and instruction. The program enables learners to import words and images on flashcards.Hence, the participants using Quizlet flashcard software showed significant differences between pre-test to post-test and pre-test to delayed post-test. Moreover, CALL provided learners opportunity to practice the target words with different types of exercises (Nakata, 2011). In this research, the participants studied the target words with Quizlet providing the flashcards, definitions, retyping exercises, different types of tests such as matching, true \& false and multiple choice questions. The program also presents gamelike activity "scatter" that requires learners to match the definitions with the target words. The increase between pre-test/ post-test and pre-test/ delayed post-test is attributable to what Mayer (2005) claimed "People learn better from words and pictures than from words alone" (p. 31).

The significant differences between the pre-test and delayed post-test results of the Quizlet group reflecting the vocabulary retention can be attributed to dual coding theory (DCT). The theory asserts nonverbal and verbal systems are two subsystems monitored cognitively (Pavio, 1971). While nonverbal system refers to the visual modalities, verbal system refers to the language. The systems can work alone, but they are also interconnected in activating one another. In this sense, the representation of a word with both verbal and imagery codes (pictures, mental images) is better than using verbal codes alone. Therefore, the interconnected memory codes provide a better chance of recalling than a single code (Pavio, 1971). This theory is exactly parallel with the results found in the present study. The participants in Quizlet group experienced the target word (verbal code) with pictures (nonverbal/ imagery code) on flashcards and other activities. Thus, the flashcard program connecting the two subsystems (verbal and nonverbal codes) gave the learners opportunity to recall the words in two weeks after delayed posttest.

Regarding the generative theory of multimedia learning, Mayer (1997) says that if the learners are exposed to verbal and visual information formats simultaneously, the possibility of recalling the information increases. That claim matches with the findings of the presentstudy because Quizlet group had chance to study the target words in both verbal and visual formats simultaneously. Thus, the significant differences between pre-test and delayed post-test illustrates the positive effect of Quizlet as a vocabulary learning tool on recalling.

Significant increases in vocabulary scores between each administration shed light to the advantages of vocabulary notebooks. The result is parallel with what Schmitt and Schmitt 
(1995) claim. They say vocabulary notebooks are crucial component of language learning for a deep understanding of the word's meaning. Keeping vocabulary notebooks helps learners to increase the vocabulary study.

"Any activity geared at committing lexical information to memory" (Hulstijn, 2001, p. 271 ) is defined as intentional vocabulary learning. This study is a sample of intentional vocabulary learning with the homework activities committing word knowledge to memory. The assignments (adapted from Schmitt \& Schmitt, 1995) including translation, making sentences, finding synonyms, antonyms and parts of speech facilitated intentional vocabulary learning. Additionally, Nation (2000) indicates intentional vocabulary learning approaches include using dictionary and flashcards. In this research, the treatment groups of Quizlet and vocabulary notebook used dictionary to find out the L2 target words' translations, synonyms, antonyms and parts of speech. Similarly, Laufer (2005) found that explicit vocabulary exercises resulted in $70 \%$ of the words being learned on immediate receptive posttest findings. Considering the vocabulary assignments in this research (finding out translations, synonyms, antonyms, parts of speech and making sentences), Laufer's findings (2005) are in line with the results of study here because the assignments consisted of explicit vocabulary exercises and posttest scores increased significantly.

Many studies on computer-based flashcard program with multimedia possibilities increase learners' motivation (Allum, 2004; Hulstijn, 2001; Nation, 2001). These claims match with the computer-based flashcard program used in this study. Quizlet, flashcard software program integrates multimedia capabilities through providing the definitions and the pronunciation of the target words, so the participants easily got the meaning with correct pronunciation. In a similar vein, a study carried out by Altiner (2011) indicated the effect of multimedia options on learners' motivation. In her study, a computer based flashcard program, Anki with no multimedia possibilities was used. The participants interviewed revealed that the program would be much more interesting and motivating for them if it provided pronunciation, definitions and example sentences of the target words. Regarding the findings, Altiner (2011) suggested computer-based flashcard programs could be more promising if language teachers integrate audio files for pronunciation and pictures into flashcards.

To sum up, overall results demonstrated Quizlet group gained slightly better outcomes than vocabulary notebook group and clearly better outcomes than control group in terms of vocabulary learning and recall. First of all, the study supported the positive effect of intentional vocabulary learning on vocabulary learning and recall. Secondly, multimedia learning and dual coding theories drawing attention to the importance of visual and verbal modalities shed light to interpret the vocabulary learning and retention results efficiently. 
Thirdly, the influence of Computer Assisted Language Learning (CALL) made Quizlet group superior to the vocabulary notebook group with its technology- based vocabulary practice opportunities.

\section{Implications}

The current study suggests practical implications in order to increase the effect of flashcard software programs and vocabulary notebooks on vocabulary learning and retention to be used for all participants including EFL teachers, learners, material designers and curriculum developers.

One of the most notable results in the current study was that Quizlet group was slightly better than vocabulary notebook group in vocabulary learning and retention. This shows that vocabulary notebooks as a vocabulary instruction tool is not exactly enough to expand vocabulary knowledge when compared to the computer- based vocabulary learning tools (ex., flashcard software programs). That is to say, the teachers, material designers and curriculum developers should not take the vocabulary notebooks for granted as the ultimate vocabulary instruction.

In the present study, the learners keeping vocabulary notebooks did not choose the words they preferred. Instead, the teacher determined the target words and vocabulary assignments to be practiced. In this sense, the interviews with the notebook group shed light to the absence of learner autonomy contrary to the assertions by Fowle (2002), who claims vocabulary notebooks help learners to control their vocabulary learning process in addition to the increase in vocabulary learning. Thus, in order to increase learner independence, ideal ways of keeping vocabulary notebooks advocated by McCarthy (1990) and Schmitt and Schmitt (1995) might be followed. They suggest the learners ought to choose the words they prefer to include, structure the notebooks on their own, and decide what information they want to note down. This applies for the EFL teachers aiming to expand the learners' vocabulary knowledge.

\section{Conclusion}

According to the results of the current study, the control group with no tool, the Quizlet group with flashcard software and the vocabulary notebook group improved. The vocabulary learning tools (Quizlet and vocabulary notebook) have an effect on vocabulary learning and retention.

It can be concluded that the findings of the present study are consistent with the dual coding theory and multimedia learning theory. The Quizlet group using verbal and non-verbal 
modalities simultaneously showed significant differences between pre-test/post-test and pre-test/delayed post-test. The results of the research are also consistent with computer assisted language learning (CALL). The participants regarding computer-based flashcard program, Quizlet gained successful outcomes.

The findings of the current research also support explicit vocabulary learning because the control group with no treatment got the lowest scores in vocabulary learning and recall. The treatment groups practicing assignments including the samples of intentional vocabulary learning such as translations, finding out synonyms, antonyms provided learners explicit vocabulary learning with better learning and retention outcomes.

\section{References}

Allum, P. (2004). Evaluation of CALL: Initial vocabulary learning. ReCALL, 16(2), 488-501.

Altiner, C. (2011). Integrating a computer-based flashcard program into academic vocabulary learning. (Master of Science Dissertation).Retrieved from Proquest Dissertations and Theses database. UMI No. 1498719.

Ashworth, D. (1996). Hypermedia and CALL. In M.C. Pennington (Eds.), The power of CALL (pp. 79-95). Hong Kong: Athelstan.

File, K. \& R. Adams (2010). Should vocabulary instruction be integrated or isolated?,TESOL Quarterly, 4, 222-249.

Fowle, C. (2002). Vocabulary notebooks: Implementation and outcomes. ELT Journal, 56(4),380388.

Hasebrook, J.P. (1997). Learning with multimedia and hypermedia: Promises and pitfalls. Paper presented at Fifth European Congress of Psychology, Dublin. Retrieved from http://www. unioldenburg.de/zef/cde/media/readings/apahyper.pdf

Hulstijn, J. (2001). Intention and incidental second language vocabulary learning: A reappraisal of elaboration, rehearsal, and automaticity. In P. Robinson (Eds.), Cognition and second language instruction (pp. 258-286). Cambridge: Cambridge University Press.

Hulstijn, J. H., \&Laufer, B. (2001).Some emprical evidence for the involvement load hypothesis in vocabulary acquisation.Language Learning, 51, 539-558. doi: 10.1111/0023-8333.00164

Kilickaya, F.,\&Krajka,J., (2010). Comparativeusefulness of onlineandtraditionalvocabularylearning. TOJET: TheTurkish Online Journal of EducationalTechnology, 9, 55-57.

Kelly, P. \& Ma, Q. (2006) Computer assisted vocabulary learning: Design and evaluation. Computer Assisted Language Learning, 19(1),15-45.

Laufer, B. (2003). Vocabulary acquisition in a second language: Do learners really acquire most vocabulary by reading? Some empirical evidence. Canadian Modern Language Review, 59, 565585 .

Laufer, B. (2005). Focus on form in second language vocabulary learning. EUROSLA Yearbook, 5, 223-250. 
Laufer, B., \& Goldstein, Z. (2004) Testing vocabulary knowledge: size, strength, and computer adaptiveness, Language Learning, 54(3), 399-436.

Levy, M. (1997). CALL: Context and Conceptualisation. Oxford: Oxford University Press.

Mayer, R. E. (1997). Are we asking the right question? Educational Psychologist, 32, 1-19.

Mayer, R.E. (2001). Multimedia learning. New York: Cambridge University Press.

Mayer, R.E. (2005). The Cambridge handbook of multimedia learning. New York: Cambridge University Press.

Mayer, R. (2009). Multimedia Learning.Retrieved from http:// dx.doi.org/ 10.1017/ CB09780511811678.003

McCarthy, M. (1990).Vocabulary. Oxford: Oxford University Press.

McCrostie, J. (2007). Examining learner vocabulary notebooks.ELT Journal, 61(3),246-255.

Nakata, T. (2011). Computer- assisted second language vocabulary learning in a pair- associate paradigm: A critical investigation of flashcard software. Computer Assisted Language Learning, 24(1),17-38.

Nation, I. S. P. (2000).Learning vocabulary in another language.Cambridge: Cambridge University Press.

Nation, I. S. (2001). Learning Vocabulary in Another Language. Cambridge: Cambridge UniversityPress.

Paivio, A. (1971). Imagery and Verbal Processes. New York: Holt, Rinehart \& Winston.

Paivio, A. (1986). Mental representations: A dual coding approach. Oxford: Oxford University Press.

Quizlet (2016).Our mission. Retrieved from http://quizlet.com/mission

Schmitt, D. \& Schmitt, N. (1995) Vocabulary notebooks: Theoretical underpinnings and practical suggestions. ELT Journal, 49(2), 133-143.

Schmitt, N. (2008). Instructed second language vocabulary learning.Language Teaching Research, 12(3), 329-363.

Watts, N. (1997). A learner-based design model for interactive multimedia language learning packages.System, 25, 1-8.

Webb, S. (2009). The effects of receptive and productive learning of word pairs on vocabulary knowledge.RELC Journal, 40, 360-376.doi: 10.1177/0033688209343854

Wilkins, D. A. (1972).Linguistics in Language Teaching. London: Arnold. 
